\section{Influence of diet quality on lower urinary tract}

Djordje Argirović ${ }^{1}$, Aleksandar Argirović ${ }^{2}$

${ }^{1}$ Oupatient Clinic „Argirović“, Urology, Belgrade, Serbia

${ }^{2}$ Clinical Hospital Center ,Zemun-Belgrade“, Department of Urology, Zemun, Serbia

\section{Abstract}

There is relative paucity of literature evaluating the association between diet and lower urinary tract symptoms (LUTS). The goal of the study was to evaluate the association between dietary quality and the prevalence of LUTS. Our hypothesis was that healthy balanced diet would be associated woth lower LUTS. Research comprised 852 patients aged $>40$ years of which $724(85 \%)$ completed urinary questionnaire. We used bivariate analysis to examine rate of LUTS among men with poor vs. good diet. Multivariate regression analysis was applied to determine impact of demographic samples in men with and without LUTS and controling for age, urban/rural population, smoking status, diabetes, alcohol intake, obesity end exercise. After exclusion of 31 men with prostate cancer, our study included 693 men, of whose $139(20 \%)$ reported at least one symptom suggestive of LUTS (63 irritave, 46 obstructive and 30 both symptoms). Men with LUTS were more likely to be rural $(p<0.0001)$, nonsmoker $(p<0.0001)$, to have diabetes $(p<0.0001)$, to be older $(p<0.0001)$, to have higher PSA $(p<0.0001)$, and to have diagnosis ofenlarged prostate $(p<0.0002)$. Moderate and vigorous physical activity and alcohol intake were more commom in men without LUTS $(p<0.0001)$. We observed higher rates of LUTS among men with poorer dietary intake of dairy $(22.4 \%$ vs. $16.4 \%)(\mathrm{p}=0.0013)$, and among men with poor protein intake $(24.6 \%$ vs. 17.95$)$ $(\mathrm{p}=0.012)$, as well as among those with overall poor diet $(25.8 \%$ vs. $17.8 \%)(\mathrm{p}=0.001)$ and with little diatery variety $(26.1 \%$ vs. $17.6 \%)(\mathrm{p}=0.001)$. On multivariate study, an unhealthy diets, rural population and older men were associated with higher LUTS degree, whereas alcohol intake was protective from LUTS. This study demonstrated that poor diet quality was independently associated with patient-reported LUTS.

Key words: lower urinary tract symptoms, diet, risk factors.

\section{Uticaj kvaliteta ishrane na simptome donjih partija urotrakta}

Đorđe Argirović1 ${ }^{1}$, Aleksandar Argirović

${ }^{1}$ Poliklinika „Argirović“, Urologija, Beograd, Srbija

${ }^{2}$ Kliničko Bolnički Centar „Zemun-Beograd“", Služba urologije,

Zemun, Srbija

\section{Apstrakt}

Postoji relativno malo podataka u literaturi koji imaju za cilj procenu korelacije između kvaliteta ishrane i simptoma donjih partija urotrakta (SDPU). Cilj ove studije je da proceni povezanost izmedju kvaliteta ishrane i SDPU. Naša hipoteza je bila da je izbalansirana zdrava ishrana udružena sa manjom učestalošću SDPU. Studija obuhvata 852 pacijenata starosti $>40$ godina od kojih je 724 (85\%) kompletiralo urinarni upitnik. Primenjena je bivarijantna analiza da se ispita stepen SDPU kod pacijenata sa dobrom i lošom ishranom. Multivarijantna regresiona analiza je primenjena da se proceni uticaj demografskih faktora kod pacijenata sa ili bez SDPU u zavisnosti odgodina starosti, pušenja, dijabetesa, konzumiranja alkohola, gojaznosti i fizičke aktivnosti. Pošto smo isključili iz analize 31 pacijenta sa karcinomom prostate, naša studija je obuhvatala 693 muškaraca od kojih je 139 (20\%) imalo najmanje jedan simptom indikativan za SDPU (63 iritativne, 46 opstruktivne i 30 oba simptoma). Veća verovatnoća za pojavu SDPU je postojala kod seoske populacije $(\mathrm{p}<0.0001)$, nepušača $(\mathrm{p}<0.0001)$, dijabetičara $(\mathrm{P}<0.0001)$, starijih muškaraca $(\mathrm{p}<0.0001)$, sa višim PSA $(p<0.0001)$ i dijagnozom uvećanja prostate $(p<0.0001)$. Umerena $i$ intenzivna fizička aktivnost $i$ unos alkohola su bili češće zastupljeni kod muškaraca bez SDPU $(\mathrm{p}<0.0001)$. Nadjena je veća učestalost SDPU kod muškaraca sa malim unosom mlečnih proizvoda (22.4\%:16.4\%) $(\mathrm{p}=0.0013)$, oskudnim unosom proteina $(24.6 \%: 17.9 \%)(p=0.012)$, generalno lošom ishranom (28.2\%:17.8\%) ( $\mathrm{p}=0.012)$ i malom raznolikošću ishrane $(26.1 \%: 17.6 \%)(\mathrm{p}=0.001)$. Multivarijantna analiza je pokazala da nezdrava ishrana, seoska populacija i stariji muškarciimaju veći rizik za pojavu SDPU, dok je unos alkohola imao protektivno dejstvo na SDPU.

Ključne reči: simptomi donjih partija urotrakta, ishrana, faktori rizika 


\section{Introduction}

There is a relative paucity of literature evaluating association between diet quality and LUTS, and the findings of these studies are heterogenous and conflicting. Investigators are increasingly interested in the relationship between enviromental/lifestyle and LUTS. For example, obesity, stress ${ }^{1}$, and type II diabetes, all linked to lifestyle, also appear to be associated with an increased the risk of developing LUTS. Conversely, a healthier lifestyle with higher levels of exercise and moderate drinking, appear to decrease the risk of LUTS ${ }^{3}$. Although the causal pathway remains uncertain, it has been hypothesized that a healthier lifestyle may lower the incidence of LUTS through the effect on sympathetic tone, androgen levels and inflamation.

The relationship between our individual diets, perhaps our most modifiable and unique lifestyle factor, and urinary symptoms remain ill defined. Although clinicians commonly hypothesis an association between the typical american diet and LUTS 5 , empirical data are limited with most of the existing studies reaching inconclusive or contradictory findings ${ }^{5-7}$.

The aim of the present study was to evaluate the association between dietary quality and the prevalence of lower LUTS. We hypothesized that a healthy balanced diet would be associated with fewer urinary symptoms.

\section{Material and methods}

Research comprised 851 patients requiring urological care aged $>40$ years of which $724(85 \%)$ completed International Prostate Symptom Score (IPSS) urinary questionaire between January 2010 and December 2012. Dietary quality was assesses using the 10 component United States Department of Agriculture (USDA) Healthy Eating Index (HEI). We used bivariate analysis to examine rates of LUTS amog men with poor vs. good diet. Multivariate logistic regression analysis was used to calculate odds ratios (ORs) after sample weights and controling for age, urban/rural population, smoking status, diabetes, alcohol intake, obesity and exercise.

\section{Results}

After exclusion of 31 men with prostate cancer, our study finally included 693 men, of whom 139 (20\%) reported at least one symptome suggestive of LUTS, with mean age of 59.1 \pm 13.2 years (63 irritative, 46 obstructive and 30 both symptoms) (Table 1.).

\begin{tabular}{|l|c|c|c|}
\hline & No LUTS(N=554) & LUTS (N=139) & P \\
\hline Age (mean, SD) & $58.2 \pm 12.9$ & $63.0 \pm 13.4$ & $<0.0001$ \\
\hline Urban/Rural (\%) & 81.8 & 64.05 & $<0.0001$ \\
Urban & 18.2 & 35.95 & $<0.0001$ \\
Rural & 31.17 & 28.29 & $<0.0001$ \\
\hline Current smokers (\%) & 9.79 & 18.26 & $<0.0001$ \\
\hline Diabetes (\%) & 73.86 & 58.95 & 0.16 \\
\hline Alcochol intake & & $28.4 \pm 5.4$ & $<0.0001$ \\
\hline$>1$ drink per week) & $28.1 \pm 5.0$ & $2.98 \pm 7.0$ & $<0.0001$ \\
\hline BMI (kg/m $)$ & $1.70 \pm 2.54$ & 24.4 & $<0.0001$ \\
\hline PSA (ng/ml) & 11.3 & 26.7 & $<0.0001$ \\
\hline Enlarged prostate diagnosis (\%) & 38.1 & 44.74 & \\
\hline Moderate excersise (\%) & 54.5 & & \\
\hline Vigorousexcersise (\%) & & & \\
\hline
\end{tabular}

Table 1. Characteristics of patients without and with LUTS 
Men with LUTS were more likely to be either rural, nonsmokers, to have diabetes, to be older, to have higher PSA and to have diagnosis of enlarged prostate. Moderate and vigorous physical activity and alcohol intake were significantly more commom in men without LUTS (Table 2.).

\begin{tabular}{|l|c|c|c|}
\hline & $\begin{array}{l}\text { No urinary simptoms } \\
\text { (mean, 95\% CI) }\end{array}$ & $\begin{array}{l}\text { One or more urinary } \\
\text { simptoms (mean, 95\% CI) }\end{array}$ & P* \\
\hline Overall HEI & $630(62.2-63.7)$ & $60.8(53.1-62.4)$ & 0.03 \\
\hline Cholesterol & $6.8(6.5-7.1)$ & $6.3(5.8-6.9)$ & 0.18 \\
\hline Dairy & $5.8(5.5-6.0)$ & $4.9(4.4-5.4)$ & 0.005 \\
\hline Fat & $6.2(6.0-6.4)$ & $6.1(5.6-6.5)$ & 0.59 \\
\hline Fruits & $3.9(3.7-4.2)$ & $3.7(3.2-4.1)$ & 0.37 \\
\hline Grain & $6.4(6.3-6.6)$ & $6.5(6.1-6.8)$ & 0.78 \\
\hline Saturated fat & $6.9(6.7-7.1)$ & $6.6(6.2-7.1)$ & 0.42 \\
\hline Sodium & $5.1(4.8-5.3)$ & $5.8(5.3-6.3)$ & 0.02 \\
\hline Variety in diets & $8.0(7.8-8.1)$ & $7.4(7.0-7.8)$ & 0.02 \\
\hline Vegetables & $6.3(6.1-6.5)$ & $6.1(5.7-6.5)$ & 0.48 \\
\hline
\end{tabular}

All results are calculated using sample weights.

* $\mathrm{P}$ values calculated using unpaired t tests. $\mathrm{P}<0.05$ indicated statistical significance

Table 2. Healthy Eating Index scores in men without and with LUTS: bivariate analysis

Men with LUTS consumed less dairy products, and has less variety in their products, and overall, had significantly less nutritious diets by USDA standard (Table 3.).

\begin{tabular}{|l|c|c|c|c|}
\hline & \multicolumn{4}{|c|}{ Needs } \\
\hline & Poor (\%) & Improvement (\%) & Good (\%) & P value* \\
\hline Overall HEI & 28.6 & 18.6 & 17.8 & 0.015 \\
\hline Cholesterol & 22.3 & 18.0 & 18.8 & 0.14 \\
\hline Dairy & 22.4 & 19.2 & 16.4 & 0.013 \\
\hline Fat & 20.4 & 18.9 & 19.6 & 0.62 \\
\hline Fruits & 20.7 & 20.7 & 17.3 & 0.21 \\
\hline Grain & 21.8 & 18.0 & 19.8 & 0.43 \\
\hline Proteins & 24.6 & 19.8 & 17.9 & 0.012 \\
\hline Saturated fat & 22.7 & 14.8 & 19.8 & 0.34 \\
\hline Sodium & 18.2 & 18.6 & 22.4 & 0.17 \\
\hline Dietary variety & 26.1 & 21.2 & 17.6 & 0.001 \\
\hline Vegetables & 20.9 & 22.3 & 17.8 & 0.20 \\
\hline
\end{tabular}

All percentage were calculated using sampling weights.

* USDA dietary categories: poor (total score $<50$; component score $<5$ ); improvement (total score 50-80; component score 5-8); and good (total score $>80$; component score $>8$ )

*Mantel extension chi-squared test for trend ( $\mathrm{p} \leq 0.05$ indicated statistical significance.)

Table 3. Prevalence of LUTS by USDA diatery category*

We observed a significantly higher prevalence of LUTS among respondents with poor overall diet, poor protein intake, and poor dietary variety (Table 4.). 


\begin{tabular}{|l|c|c|}
\hline Model variables & OR (95\% UI) & P value \\
\hline Age $>$ 60 years & $2.4(1.6-3.1)$ & $<0.0001$ \\
\hline Population & & \\
\hline Rural & $2.8(2.0-4.0)$ & $<0.0001$ \\
\hline Diabetes & $1.4(0.8-2.5)$ & 0.24 \\
\hline Alcochol & $0.67(0.48-0.93)$ & 0.015 \\
\hline Smoking (current) & $0.95(0.66-1.36)$ & 0.77 \\
\hline Excersise & $0.76(0.46-1.25)$ & 0.28 \\
\hline BMI & $1.1(0.71-1.70)$ & 0.67 \\
\hline Overall HEI & $1.74(1.05-2.90)$ & 0.031 \\
\hline Cholesterol & $1.36(1.00-1.83)$ & 0.51 \\
\hline Dairy & $1.31(0.78-2.20)$ & 0.31 \\
\hline Fat & $1.11(0.66-1.88)$ & 0.69 \\
\hline Fruits & $1.39(0.78-2.50)$ & 0.27 \\
\hline Grain & $1.02(0.61-1.70)$ & 0.94 \\
\hline Meat & $1.10(0.75-1.59)$ & 0.63 \\
\hline Saturated fat & $1.18(0.74-1.87)$ & 0.49 \\
\hline Sodium & $0.72(0.44-1.18)$ & 0.19 \\
\hline Variaty & $1.34(0.89-2.02)$ & 0.16 \\
\hline Vegetables & $1.13(0.72-1.28)$ & 0.59 \\
\hline
\end{tabular}

Table 4. Multivariate logistic regression analysis

After controling for age, urban/rural population, diabetes, alcohol intake, BMI, excersise and smoking, the OR of LUTS in those with a least healthy diet was 1.74. Alternatively, in our adjusted analyses, there was no statisticaly significant association between any of the 10 dietary subscales and LUTS. We also observed greater odds of LUTS among unhealtly diet, rural population, older patients, whereas alcohol intake was slightly protective from LUTS.

\section{Discussion}

In this cross-sectional study of the Serbian population we found that a healthier diet was associated with lower self-reported LUTS in men over the age of 40 years. Alternatively, we found no evidence that any individual food group appeared to be protective from LUTS. We also found evidence of greater self-reported LUTS in rural population, older men and slightly reduced LUTS in patients who consumed alcohol.

A 2008 study by Kristal et al. that analyzed the incident cases of BPH among patients assigned to the placebo arm of the prostate cancer prevention trial found that a diet that included moderate alcohol intake and was high in potein and vegetables and low in fat and red meat was protective for LUTS ${ }^{8}$. A study by Chyon et al. found that beef intake slightly increased the risk of LUTS, although analysis of 32 other food groups found no increased risk ${ }^{9}$. Analysis of the Health Professional Follow-up Study found that vegetable intake was inversely correlated with LUTS but other food groups showed no strong association ${ }^{10}$. In other studies, starch, vegetable consumption, fat consumption, and poultry have shown to increase the risk of BPH and LUTS, whereas others have shown vegetables and unsaturated fats to be protective from LUTS ${ }^{11-15}$. The heterogenous patient populations, definitions used for LUTS, and analytic methods used make it difficult to draw any clear conclusions. 
We used the HEI scored generated from the Natipnal Health and Nutrition Examination Survey (NHANES) 24-hour dietary data. Use of the HEI has many advantages. First, the HEI uses an easily interpretable scoring system based on adherence to USDA deitary recommendations that precorrects for such factors as total caloric intake, body size, and individual recommended serving amount. This makes comparisonof the numbers between subgroups potentially easier. Second, the scores have been shown in other studies to correlate with the development of chronic diseases, most importantly cardiovascular disease ${ }^{16}$. Third, unlike other dietary studies that analyze individual components of diet for correlation with disease, the HEI is intended to analyze the overall healthiness of the study partcipant's diet. Although this can be vewied as a weakness of using the HEI, as it does not easily allow one to study the effects on manipulating one dietary variable to lower LUTS (ie, studying the increase in vegetable consumption), use of the overall HEI may represent a more real-world dietary situation, in which increasing and decreasing a single dietary component may not be expected to influence disease processes of the overall diet remains poor.

How diet affects the development of LUTS is unclear, but there are potential mechanisms that have been proposed. Oxidative stress within the prostate that have been shown to increase the development of $\mathrm{BPH}^{17}$; thus healthier foods with higher level of antioxidants may decrease LUTS. The relationship has been described in a previous observational study where diets rich in antioxidants obtains from vegetable, namely beta-carotene, lutein, and vitamin C, protected participants from LUTS $^{18}$. The autonomic nervous system can also be influenced by $\operatorname{diet}^{19}$, and increased sympathetic tone can also be influenced by diet ${ }^{19}$, and increased sympathetic tone has been linked to the development of LUTS. A study by McVary et al. showed that sympathetic tone directly correlated with increasing American Urological Association Symptoms scores4. A similar link between catecholamines and life stress as it relates to urinary symptoms has been described ${ }^{1}$. Finally, androgenes, which are necessary for prostate growth and likely play a role in BPH development through influences of prostatic growth factors ${ }^{20}$, are another possible dietary mechanism for LUTS development. A decrease in the bioavailability of testosterone relative to estrogen levels has been shown to influence prostate growth ${ }^{5}$.

The finding of an inverse correlation between both alcohol intake and exercise and LUTS have been reported previously in similar study populations ${ }^{8}$. Only alcohol intake was significant on multivariate analysis, but both exercise and alcohol intake were highly correlated with a healthy $\operatorname{diet}^{9}$. Overall, these findings support a theory that a lifestyle that includes a healthy diet, exercise, and moderate alcohol intake, may decrease the risk of LUTS. Further study of how these three variables work together in the individual to decrease LUTS is certainly warranted.

The relationship between race and LUTS was an intriguiging finding from the study that has been suggested before ${ }^{21}$. Confouding variables that were not included in this analysis but have been shown to effect LUTS, including socioeconomic status and education, may explain some of the differences we found between races $^{22}$. A further consideration, however might be that the differences in LUTS reportedbetween levels of socioeconomic status and education may be in part influenced by known differences in diet, although this theory requires further investigation.

Our analysis has several limitations that warant brief mention. Our data are cross-sectional in nature, and although they can demonstrate association between diet and LUTS, they cannot show conclusively a causal relationship between diet and LUTS. Our definition of LUTS was based on only 2-self reported questions that have not been validated to describe all LUTS/BPH patients. Having a more precise questionnaire, such as IPSS, would certainly allow a better understand of the relationship between diet and LUTS. In addition, with such few men reporting 2 symptoms $(\mathrm{n}=30)$, we were unable to demonstrate a dose dependent relationship between LUTS and diet that should exist if diet is truly causal.

Despite these limitations, our analysis is noteworthy for its methodological rigor and use of contemporary and highly generazible US data. Our finding of a nearly $70 \%$ reduction of odds of LUTS among patients with the healthiest diet needs further confirmation, but suggest that diet alteration may be a potential option in the managment of this common and bothersome symptom.

MATERIA MEDICA • Vol. 30 • No. $2 \cdot$ april 2014. 


\section{Conclusion}

This study demonstrated an association between consuming less healthy diet and LUTS after controling for other modifiable risk factors. However, further investigation into the mechanism of dietary LUTS prevention is warranted.

\section{Acknowledgment}

We cordially thank to Natalija Šeparović, from Hypo Alpe Adria, Hypo Facilities Servicies, Belgrade, Serbia for help in statistical analysis and to Iva Popović, from City_Image, Belgrade, Serbia for technical assistance in realisation of this manuscript.

\section{References}

1. Ulrich PM, Lutgendorf SK, Leserman J, et al. Stress, hostility, and disease parameters of benign prostatic hyperplasia. Psychosom Med 2005; 67:476-82.

2. Rohrmann S, Smit E, Giovannucci E, et al. Association between markers of the metabolic syndrome and lower urinary tract symptoms in the Third National Health and Nutrition Examination Survey (NHANES III). Int J Obes $2005 ; 29: 310-16$.

3. Orsini N, Rashid Khani B, Anderson SO, et al. Long-term physical activity and lower urinary tract symptoms in men. J Urol 2006; 176:1546-50.

4. McVary KT, Rademaker A, Lloyd GL, et al. Autonomic nervous system overactivity in men with lower urinary tract symptoms secondary to benign prostatic hyperplasia. J Urol 2005; 175:1327-33.

5. St. Saurer JL, Jacobson DL, McGree ME, et al. Association between longitudinal changes in serum estrogen, testosterone, and bioavailable testosterone and changes in benign urologic outcomes. Am J Epidemiol 2011; 173:787-96.

6. Rohrmann S, Nelson WG, Rifai N, et al. Serum, sex steroid hormones and lower urinary tract symptomes in Third National Health and Nutrition Examination Survey (NHANES III). Urology 2007; 69:708-13.

7. Rohramnn S, Giovannucci E. Willet WC, et al. Fruit and vegetable consumption, intake of micronutrutients, and benign prostatic hyperplasia in US men. Am J Clin Nutr 2007; 85: 523-29.

8. Kristal AR, Arnold KB, Schenk JM, et al. Dietary patterns, supplement use, and the risk of symptomatic benign prostatic hyperplasia. Am J Epidemiol 2008; 167:925-34.

9. Chyon PH, Nomura AM, Stimmermann GN, et al. A prospective study of alcohol, diet and other lifestyle factors in relation to obstructive uropathy. Prostate 1993; 23:253-264.

10. Rohrmann S, Giovannucci E, Willet WC, et al. Fruit and vegetable consumption, intake of micronutrutients, and benign prostatic hyperplasia in US men. Prostate 2007; 85:523-529.

11. Rohrmann S, Crespo CJ, Weber JH, et al. Association of cigerette smoking, alcohol consumption and physical activity with lower urinary tract symptom s in older American men: findings from the Third National Health and Nutrition Examination Survey. BJU Int 2005; 96:77-82.

12. Parsons JK. Lifestyle factors, benign prostatic hyperplasia and lower tract symptoms. Curr Opin Urol 2001; 21:1-4.

13. Bravi S, Bosetti C, Dal Maso L, et al. Macronutritients, fatty acids, cholesterol, and risk of benign prostatic hyperplasia. Urology 2006; 67:1205-1211.

14. Ambrosini GL, de Klerk NH, Mackerras D, et al. Dietary patterns and surgically treated benign prostatic hyperplasia: a case control study in Western Australia. BJU Int 2008; 101:853-860.

15. Bravi S, Bosetti C, Dal Maso L, et al. Food groups and risk of benign prostatic hyperplasia. Urology 2006; 67:73-79.

16. McCullough ML, Feskanich D, Rimm EB, et al. Adherence to the dietary guidelines for Americans and risk of major chronic disease in men. Am J Clin Nutr 2000; 71:1223-1231.

17. De Marzo AM, Coffey DS, Nelson WG. New concepts in tissue specifity for prostate cancer and benign prostatic hyperplasia. Urology 1999;53 (Supp 3a):29-39.

18. Suzuki S, Platz EA, Kawachi I, et al. Intakes of energy and macronutritients and the risk of benign prostatic hyperplasia, Am J Clin Nutr 2002; 75:689-697. 
19. Appel LJ, Champagne CM, Harsha DM, et al. Effects of comprehensive lifestyle modification of blood pressure control: main results of the PREMIER clinical trial. jAMA 2003: 289:2083-2093.

20. Weihna Z, Makela S, Anderson LC, et al. A role for estrogen receptor beta in the regulation of growth of the ventral prostate. Proc Natl Acad Sci USA 2001; 98:6330-6335.

21. Fowke JH, Munro H, Signorella 1B, et al. Association between socioeconomic status (SES) and lower urinary tract symptoms (LUTS): severity between black and white men. J Ger Intern Med 2011; 26(11):1305-1310.

22. Dramon N, Drenowski A. Does social class predict diet quality? Am J Clin Nutr 2008; 61: 1107-1117.

Corresponing author:

Djordje Argirović

Outpatient Clinic „Argirović“, Urology

Cvijićeva $84 \mathrm{~A}$

11120 Belgrade, Serbia

Tel.: + 381112788 498; 2787 900,

Mob.: + 38163236659

Fax.: + 381113290324

E-mail: djordje.argirovic@gmail.com 